NBER WORKING PAPER SERIES

POLITICAL AND ECONOMIC DETERMINANTS OF BUDGET DEFICITS

IN THE INDUSTRIAL DEMOCRACIES

Nouriel Roubini

Jeffrey Sachs

Working Paper No. 2682

NATIONAL BUREAU OF ECONOMIC RESEARCH

1050 Massachusetts Avenue

Cambridge, MA 02138

August 1988

We thank-Professor Robert Gordon, Mr. Isao Kubota of the Japanese Ministry of Finance and the other participants at the ISOM Conference for many helpful comments and suggestions. We also thank Mr. Grignon of the OECD for providing us the data on the general government net debt. of course, all remaining errors are ours. This research is part of NBER's research program in Economic Fluctuations. Any opinions expressed are those of the authors not those of the National Bureau of Economic Research. 
NBER Working Paper \#2682

August 1988

\section{POLITICAL AND ECONOMIC DETERMINANTS OF BUDGET DEFICITS IN THE INDUSTRIAL DEMOCRACIES}

\section{ABSTRACT}

This paper focuses on the management of fiscal deficits and the public debt in the industrial democracies. Given the large deficits in many $O E C D$ countries in recent years, and the resulting sharp rise in the public debt, it is important to determine the economic and political forces leading to such large deficits. We find only partial support for the "equilibrium approach to fiscal policy", which assumes that tax rates are set over time in order to minimize the excess burden of taxation. Tax rates do not seem to be smoothed, and budget deficits in many countries in recent years appear to be too large to be explained by appeal to transitory increases in government spending. We suggest that in several countries the slow rate at which the post-'73 fiscal deficits were reduced resulted from the difficulties of political management in coalition governments. There is a clear tendency for larger deficits in countries characterized by a by a short average tenure of government and by the presence of many political parties in a ruling coalition.

Nouriel Roubini Department of Economics Yale University New Haven, CT 06520
Jeffrey Sachs

Department of Economics

Harvard University

Cambridge, MA 02138 
It is only recently that mainstream macroeconomists have made an important effort to formulate a positive theory of government behavior. The traditional macroeconomics literature took government policy variables to be exogenous, and examined the comparative statics effects of aiternative policy choices. More recently, normative rules of behavior for government polfcy were derived based on structural macroeconomic models combined with simply objective functions assigned to the government. As a general rule, there was little interest in explaining what governments actually did, but only interest in explaining what governments ought to do in order to accomplish certain objectives.

Macroeconomists are now recognizing the need to explore more carefully what governments actually do, rather than what they ought to do. The first reason for this change of emphasis is simply the overwhelming and ever-increasing role of the goverment in modern Industrial economies. For example, with the share of government spending in GNP now more than 40 percent in most OECD economles, up significantly from the early 1960s, It is obviously of fundamental 1mportance to understand the forces behind actual government spending decistons.

Second, modern economic theory stresses that intertemporally optimising Individuals must form expectations about future government policles as a key part of their decisiomaking process. In order to form expectations, it is crucial to understand the nature of government behavior in order to derive appropriate expectations about future policies. If private agents are forming expectations over future government policies, macroeconomists must do the same in order to get an acceptable model of the macroeconomy. 
Third, many economists blame faulty macroeconomic policles for the poor macroeconomic performance of much of the world economy since the early 1970s. A long and growing list of apparent policy failures (e.g. the inflationary monetary policles in the industrial countries during the 1970s, the large budget defic1ts in the U.S. and elsewhere in the 1980s) have led many economists to ask whether there are systematic biases in government decisionmaking or political incentives that lead to poor economic policies.

One 1mportant possibility, for example, explored in the 1mportant contributions of Kydland and Prescott (1977) and Barro and Gordon (1983a, 1983b), is that optimal policles are time Inconsistent, so that actual government policies may deviate importantly from optimal policies if governments cannot commlt their future actions. This literature has led to an important theoretical exploration of key ideas such as the reputation of policymakers; the difference of "statutory" versus "constitutional" limitations on policymaking; the role of institutions (e.g. central bank Independence) on economic outcomes, and so on.

Our paper focuses on a specific, but important area of macroeconomic policymaking: the management of fiscal deficlts and the public debt. Given the large deficits in many economies in recent years, and the resulting sharp rise in the public debt, it is important to determine the economic and political forces leading to such large deficits. The basic data that motivates our exploration is given in Table 1. There we see the very sharp $r i s e$ in the share of taxes and aggregate spending in the national economies of the major industrial countries in 
the past 25 years, as well as the large budget deficits in many of the economies in recent years. (Here as elsewhere in the paper, our measure of the budget deficit is not the financial balance of the general government, as is typically reported, but rather the change in the rat lo of net public debt to GDP). In three countries, Belgium, Ireland, and Italy, the ratio of net debt to GDP has reached remarkable levels of around 100 percent or more.

Our starting point of analysis is the so-called nequllibrium approach to fiscal policy, which has been champloned by Barro $(1979,1983$, 1985, among other works), and recently summarlzed by Aschauer (1988). This approach argues that actual tax and deficit policies are a reflection of an intertemporal optimization over a long time horfzon by the budgetary authorities, who choose their polictes to reduce the excess burden of taxation for a given path of government spending. While this viewpoint, sometimes summarized as the "tax smoothing" hypothesis of government budgetary policy, offers some 1mportant Insights, it does not fully account for the differences in the magnitudes of budget deficits across OECD economies in recent years. It also seems to be inconsistent with the

1. This cholce of measure is motivated by several considerations. First. It is the varlable used by Barro and others in testing the taxsmoothing hypothesis of bt management. Second, the typically reported measure of fir.: al balances overstates the economically relevant deficit by including the inflation component of interest payments on the public debt, which should be counted properly as a form of debt repayment rather than a current budgetary expenditure. The change in the net-debt-to-GNP ratio automatically adjusts for this component. Third, the long-run tax implications of current deficits are best measured by looking at the net-debt-to-GNP ratio. Note that to the extent that conventionally measured deficits are financed by seignorage (i.e. the inflation tax) rather than by debt accumulation, our measure will understate the deficit. Put another way, we implicitly count seignorage as a form of taxation rather than as a form of deficit financing. 
steady rise in tax rates in most of the OECD economies during the past two decades.

Our main goal is to demonstrate that differing institutional arrangements in the political process in the various OECD economies also help to explain the markedly different patterns of budget deficits in the different countries. Of course, the public choice approach to budgets (as developed by James Buchanan and others), and the recent so-called "partisanship theory" of pollcymaking, of Alesina, Havrilesky, Sachs, Tabellini, and others, have also drawn our attention to some of the important political features of budget management, by recognizing the role of political conflict in affecting budgetary policy. However, these theories have not stressed enough the role of alternative political institutions in mediating the effects of political conflict on budgetary outcomes.

We wish to stress in our analysis that governments are not the monolithic entities of standard economic models that have full control of the policy instriments and that manage them according to a stable and well-defined objective function. When power is dispersed, either across branches of the government (as in the U.S.), or across many political parties in a coalition government (as is typical in Italy), or across parties through the alteration of political control over time, the likelihood of intertemporally inefficient budgetary policy is heightened. Thus, we find that the size and persistence of budget deficits in the industrial countries in the past decade is greatest where there have been divided governments (e.g. multi-party coalitions rather than majorityparty governments). 
Some basic support for this view is garnered in Table 2. There we show the pattern of budget deficits during 1975-86, together with the "typical" institutional form of the government, and the average tenure of governments. It is apparent that governments with large coalitions and/or short tenures (e.g. Belgium, Italy, Sweden, and Denmark) are characterized by particularly large average budget deficits in the past decade. ${ }^{2}$ While there are exceptions to this proposition (e.g. the Netherlands, and Finland for reasons described in footnote 2 and later), there are no cases of long-lived governments (with an average tenure greater than 3 years) showing an average annual change in the debt-GDP ratio in excess of 3 percentage points during the perlod 1975-85.

The importance of the time-horizon of the government for budget policy has recently been stressed in an important paper by Alesina and Tabellini (1987). They emphasize that when political power alternates randomly between competing political parties, each government will be tempted to leave a legacy of high debt for its successor, whose spending

2. Later we will discuss a political classification scheme in greater detail. Suffice it here to note that Finland and France present certain ambiguities in classification, since they are mixed parliamentary - presidential systems. In both cases, we treat them more as presidential than as parliamentary systems, and therefore expect them to show low budget deficits on average. In France, the ambiguity in form is not highly problematical, since even as a parliamentary system, France would be classified as a small coalition case (with coalition partners that are typlcally rather simflar in ideology). In Finland, there is much greater problem, however. Finnish coalition governments are typically multi-party, and extend over a very wide ideological range. Therefore, in its parliamentary aspect, the Finnish government has the kind of structure that seems to give rise to large budget deficits in other countries. We believe that the strong presidency overcomes many of the problems that would otherwise arise. Some observers stress that Finland has behaved more like a presidential than parliamentary system in part because of the personal political strength of the long-time president of the postwar period, Mr. Kekkenon. 
priorities it is not likely to share. The high debt restralns the spending by the next government, but the current government cares little about the next government's spending in any case. Presumably, the more rapid the turnover of government, the more important would be this deficit bias effect.

We also stress the role of rapid turnover of governments, but through a different channel. In our interpretation, the problem of coalition governments is the inablity to secure agreements among coalition partners within a given government. The shorter is the expected tenure of the government, the more difficult it may be to achieve cooperation among the coalition partners (game theory establishes the general point that cooperation is easier to maintain the longer is expected time horizon over which agents will interact).

A word should be sald at the beginning about the possibility of reverse causality in the correlation that we are stressing. Might not large and persistent budget deficits account for the weak and mult-party character of some countries, rather than vice versa? This alternative interpretation is in fact highly doubtful, since: (1) the regime character depends intimately on the constitutional process (e.g. most importanty, whether elections are governed by proportional representation, which tends to produce short-lived multi-party coalition governments); (2) the regime character is highly stable over time, and is little influenced by the budgetary situation.

The paper is organized as follows. Section II examines the "equilibrium" approach to fiscal policy. While the theory offers interesting insights, some key aspects of the theory are not supported by 
7

the data for several OECD economies. Section III sheds some light on the origins of the large budget deficits after 1973 in many OECD economies. We attribute the onset of large deficits to the growth slowdown and rise in unemployment after 1973, as well as the sharp rise in real interest. rates after 1979. By the early 1980s, most governments recognized that large budget deficits were likely to continue in the absence of major adjustments in spending and taxes, but only some countrles (notably the Germany, Japan, and the U.K. among the major economies) successfully stabilized the ratios of public debt to GDP. Section IV suggests that the success of fiscal consolidation has been importantly related to political institutions.

Section II. The Equilibrium Model of Fiscal Policy

Our starting point of analysis is the equilibrium approach to fiscal deficits. The equilibrium model is based on the following assumptions: (1) the time path of future government spending is given, and is known; (2) the discounted value of taxes is equal to the discounted value of future government spending plus the initial stock of public debt; (3) the time path of taxes has no effect on output via aggregate demand; and (4) the excess burden of taxation is a convex function of the tax rate. It is assumed that the government chooses taxes to minimize the present discounted value of the deadweight burden of taxation.

Given these assumptions, it is easy to prove the celebrated "tax smoothing" hypothesis, which holds that taxes are set at the fixed rate that minimizes the intertemporal deadweight loss of the tax system. To show this result, let $G_{1}, G_{2}, G_{3}$, . . be the exogenous time path of 
real government spending. GNP in period $t$ is denoted by $Y_{t}$. Let $g_{1}, g_{2}$. $\mathrm{g}_{3}$, . . be the path of government spending relative to GNP, i.e. $g_{t}$ $G_{t} / Y_{t}$. Let $T_{1}, T_{2}, T_{3}, \ldots$. be the time path of taxes, and let $t_{1}, t_{2}$, $t_{3}$,... be the time path of taxes relative to GNP (we w111 also call $t_{t}$ the tax rate in perlod $t$ ). The real interest rate is given and (for convenience only) is fixed at the rate $r$. The stock of public debt in real terms at the beginning of period $t$ is denoted by $B_{t}$. The public debt evolves according to the dynamic budget constraint:

$$
\text { (1) } B_{t+1}=(1+r) \star B_{t}+\left(G_{t}-T_{t}\right)
$$

$\left(G_{t}-T_{t}\right)$ is the primary budget deficit. We will denote the debt-GNP ratio as $b_{t}-B_{t} / Y_{t}$.

The taxes are assumed to be distortionary, with deadweight losses per unit of GNP given by $D\left(t_{t}\right)$, with $D^{\prime}>0$ and $D^{\prime \prime}>0$. The governments intertemporal loss function as of period $t$ is given by:

$$
\text { (2) } L_{t}-\sum_{I=0}^{\infty}(1+r)^{-1} D\left(t_{t+1}\right) * Y_{t+1}
$$

Under the assumptions of the equilibrium model, the goal of the government as of period $t$ is to find the time path of taxes which minimizes (2) subject to the constraint that the discounted value of taxes equal the discounted value of expenditures:

$$
\text { (3) } \sum_{i=0}^{\infty}(1+r)^{-(1-1)} T_{t+i}-(1+r) B_{t}+\sum_{i=0}^{\infty}(1+r)^{-(i-1)} G_{t+i}
$$

It is straightforward to show that the first-order conditions for the government's optimal tax program are simply: 

(4) $D^{\prime}\left(t_{t+i}\right)=\lambda$
for all $i=0,1,2, \ldots$

where $\lambda$ is the Lagrange multiplier assoclated with the intertemporal constraint that total taxes must equal total expenditure. From (4) it is obvious that the tax rate should be set at a constant value across all future time periods, consistent with the intertemporal budget constraint in (3).

In a stochastic environment, the equivalent condition for optimal tax smoothing is that the tax rate is a random walk without drift, and that changes in the tax rate between period $t-1$ and $t$ are unpredictable given the information set at time $t-1$.

To find the appropriate constant value of taxes for the model (1)-(4), it is convenient to define the "permanent" level of government spending relative to income as follows. Let $n_{i}$ be the compounded growth rate of real GNP between period $t$ and perlod $t+1: Y_{t+1}=Y_{t} \star(1+$ $\left.n_{i}\right)^{i}$. Then, the discounted value of government spending can be written as:

$$
\begin{aligned}
(1+r)^{-1} G_{t+1}=(1+r)^{-1} Y_{t+1} g_{t+1} \\
-(1+r)^{-i}\left(1+n_{i}\right)^{i} g_{t+1} Y_{t}
\end{aligned}
$$

Let $g^{P}$ be the constant level of $g_{t}$ starting at time $t$ such that the discounted value of $g_{t}^{P}$ is the same as the discounted value of the actual path of $g_{t}$. Specifically:

(6) $g_{t}^{p}=\left[\sum_{i=0}^{\infty}(1+r)^{-i}\left(1+n_{i}\right)^{i} g_{t+i}\right] /\left[\sum_{i=0}^{\infty}(1+r)^{-i}\left(1+n_{i}\right)^{i}\right]$

In the special case where growth $n_{i}$ is constant $n,(6)$ reduces to the simpler expression: 
(7) $g_{t}^{p}-\{(r-n) /(1+r)]\left|[(1+r) /(1+n)]^{-1} g_{t+1}\right|$

It is now straightforward to show that the approprlate constant tax rate $t^{c}$ is given as follows:

(8) $t^{c}=(1+r) * \alpha * b_{t}+g_{t}^{p}$ where $a-\sum_{1=0}^{\infty}(1+r)^{-1}\left(1+n_{1}\right)^{1}$. In the case where the growth rate $n$ is constant, we can write:

(9) $t^{c}=(r-n) b_{t}+g_{t}^{p}$

The important implication of (8) and (9) is that the tax rate is optimally set at the level of permanent spending, plus a fraction of the interest payment due on the outstanding stock of debt. It is then straightforward to show that the change in the debt-GNP ratio may be written as follows (in the constant $n$ case):

(10) $\left(b_{t+1}-b_{t}\right)-[1 /(1+n)]\left(g_{t}-g_{t}^{p}\right)$

According to (10), the debt-GNP ratio is a function of the gap of temporary and permanent government spending. When government spending is above its permanent level, $b_{t}$ rises, and when government spending is below its permanent level, $b_{t}$ falls.

Equation (10) is the basis for Barro's celebrated emphasis on. deficits and wartime. During wars, $g_{t}$ will greatly exceed $g_{t}^{P}$, and debt will rise. During peacetime, $g_{t}$ will tend to be less than $g_{t}^{p}$ (because $g_{t}^{P}$ will included expected expenditures of future wars), and the debt-GNP 
ratio should fall. Barro has conflrmed these basic trends for peacetime and wartime for the U.S. and the U.K.

As another 1llustration of equations (9) and (10), consider the case in which government spending relative to GNP is rising each period, as has been the case in several European countrles. Suppose that $B_{t}$ rises by the amount $\gamma$ each perlod, so that $g_{t+1}=g_{t}+1 * \gamma$. Then, permanent spending is always above temporary spending, by the amount $\gamma /(r-n)$. Therefore, we would find from (9) that taxes are always above current government spending plus $(r-n) b_{t}$ by the same amount:

$$
\text { (11) } t^{c}-g_{t}+(r-n) b_{t}+\gamma /(r-n)
$$

The debt-GNP ratio would always be falling, according to:

(12) $b_{t+1}-b_{t}--[1 /(1+n)] * r /(r-n)$

The economic interpretation of (12) is as follows. In order to minimize the excess burden of taxation, the tax rate should be held constant, despite the constant rise in the rate of government spending. But how can this be done if government spending is constantly rising as a proportion of GNP? Taxes should be set to generate a budget surplus, leading to a declining ratio of debt to GNP, so that the interest payments on the debt as a fraction of income fall over time, to compensate for the constant rise in non-interest government expenditure.

Testing the Equilibrium Approach for the OECD Economies

The equilibrium approach stands in strong contrast to the pessimistic forebodings of some economists (notably Buchanan and Tullock), 
who claim that there is a chronle tendency towards budget deficits in representative democracles. The equllibrium view predicts falling debt. GDP ratios during normal peacetime years. As shown in Table 3 , the prediction of falling $b_{t}$ was strikingly confirmed for most industrial countrles during the period 1960 to 1973. Debt-GDP ratios fell in the U.S., France, the U.K., Canada, Belgium during the perlod, or in 5 of the 7 countries with net debt data as far back as the mid-1960s. Only Italy and Germany showed a contrary trend, and in the case of Germany, the level of the net debt was negative or insignificant unt1l the mid-1970s. Thus, at least for the years 1960-73, there is little evidence of a chronic bias towards deficits.

Even during the 1960 and early 1970s, however, the OECD fiscal data are not wholly kind to the equilibrium model. While taxes are high enough in most countries to result in a falling debt-GNP ratio, they are decidedly not high enough at any point in time to allow for smooth taxes in the face of a rising rate of govermment spending. In particular, in most countries, the share of government spending in GNP rises steadily, and the share of taxes in GNP rises steadly glong side the higher share of government spending. In other words, rather than being set in order to smooth the tax rate, as in equation (11), taxes are set along a rising path to keep them roughly aligned with government spending. As is shown In Table 4, tax rates (measured as government revenues as a proportion of GDP) rose quite markedly and steadlly during 1960-73 in most countries, and have in fact continued to rise steadily during the period 1973-1986.

The most direct statistical test of the tax-smoothing model is to ask whether the observed path of tax rates is likely to have been 
generated by a mean-zero random walk, versus an alternative hypothesis in which the changes in $t_{t}$ have a constant non-zero drift. Table 5 reports the regression results of the null hypothesis of a pure random walk for tax rates, first for the perfod 1960-73 and then for the overall period 1960-86. We test the shorter period first to make certain that our results are not simply some artifact of the low-growth phase after 1973 .

In the short sample, the null hypothesis of a driftless random walk in tax rates is rejected at the 5 percent level for 7 of the 12 countries for which tax data are available back to 1960 . For the longer sample, the null hypothesis is rejected for a whopping 12 out of 15 countries (the U.S., the U.K., and Finland being the only exceptions). It is also rejected at the 10 percent level for the U.K. In the larger sample. It would seem, therefore, that Barro's $(1979,1981)$ earlier results supporting the tax-smoothing model for the U.S. and the U.K. are rather special cases. Note that for the U.S., Sahasakul (1985) has also rejected the random-walk model for taxes. That rejection is not because of a constant drift (as in our test), but instead because of the finding that other variables help to predict future changes in U.S. tax rates.

The equilibrium theory's presumption of peacetime declines in the debt-GNP ratio is turned on 1ts head after 1973. Between 1973 and 1986, the net-debt-to-GDP rat1o rose in 13 of 15 cases shown, with the U.K. and Norway being the only exceptions. This is an extraordinary turnabout for peacetime years. It is certainly possible that as the likelihood of war fell sharply during the 1960 s and 1970 s for the European countries, the estimation of $g_{t}{ }_{t}$ fell as well, leading to a reduction in the optimal peacetime surplus for these countries. But such a shift (if 
it could be proved) would hardly be sufflclent to explain the dramatic rise in $b_{t}$ in many countries. We are led, therefore, to ask whether other shocks might have led to an excess of $g_{t}$ over $g_{t}{ }_{t}$ during these years that could explain the rise in debt consistently with the equilibrium theory. Our answer is mixed. In the next section we identify some important shocks (mainly the growth slowdown in the OECD after 1973 and the accompanying rise in unemployment) that probably raised $g_{t}$ relative to it permanent level, at least for part of the period after 1973. On the other hand, the rate at which $g_{t}$ has declined relative to its previous trend seems to have been too slow in many countries to suggest that optimal tax smoothing is at work. As we have already noted, taxes as a percent of GNP have trended upward rather strongly in most OECD countries in the years after 1973. Moreover, the equilibrtum approach would appear to offer little explanation of the glaring fact that in some countries (e.g. Germany, Japan, and the U.K.) the rise in the debt-GNP ratio was stopped by the mid-1980s, whlle in other countries (e.g. Belgium and Italy), the rise has continued. To help account for these differences, we must turn to differences in political institutions.

Before examining the large post-1973 deficits, we test one further implication of some versions of the equilibrium model. A minor (and much less plausible) implication of the tax smoothing model involves the government's choice over different kinds of taxes. Recently, Mankiw (1987) suggested that since inflationary finance is one kind of tax (to. wit, a tax on real money balances), and since the goal of the tax authorities is to minimize the overall excess burden of taxation, a rising path of total revenues relative to GDP should be met by a rise both in 
explicit tax rates and a rise in the inflation tax (the efficlency rule is that the varlous taxes should be levled to the polnt where the deadwelght loss per dollar of marginal revenue is equalized across the avallable array of taxes). Manklw tests this proposition by examining the correlation of explicit tax rates with the Inflation rate (which is taken as a proxy of the tax rate on real money balances). Using U.S. data, he finds a positive and signiflcant correlation, In support of the underlying hypothesis.

In Table 6, we extend Mank1w's test to the other Industrial countrles in our sample, by regressing the inflation rate on the average rate of taxation. The hypothesis finds no general support. For 12 of the 15 countries, we find no significant relationshlp, and in five of the countries (France, Austr1a, Italy, Ireland, and Denmark), the sign of the regression coefficlent is wrong (inflation and tax rates are negatively correlated) ${ }^{3}$. We confirm Mank1w's result for the U.S., and also find supportive results as well for Finland and the Netherlands.

III. The Post-1973 Rise in Budget Deficits in the OECD

Our basic interpretation of the emergence of large budget deficits in the OECD after 1973 is on the whole consistent with the equilibrium viewpoint. The sudden and sharp increase in budget deficlts after 1973 can be linked directly to the sudden slowdown in OECD growth and the corresponding sudden rlse in unemployment after 1973. These shocks increased $g_{t}$ on what appeared to be a cyclical basis, and so the

3. In a recent paper Poterba and Rotemberg (1988) perform similar tests for 5 OECD countries and provide further evidence against the optimal theory of seignorage. 
shocks increased $g_{t}$ relative to expectations of $g_{t}{ }^{p}$. Since it was widely expected during the 1970 s that the growth slowdown and the rise in unemployment would be transitory, it is consistent with the equilibriur view that these shocks would be accommodated initially by budget deficits.

By the early 1980s, however, it had become clear that the shocks had considerable persistence (to the point of spawning the new "hysteresis" theory of unemployment), and many governments began reducing the budget deficits. In broad terms, the equilibrium approach is much less successful in accounting for the persistence of budget deficits throughout the 1980 s in many countries. (Remember, as well, that in almost all countries, the theory fails to account for the steady secular increase in tax rates from the early 1960s). .

The linkage of higher $g_{t}$ to the post-1973 growth slowdown arises from several channels. As is described in the detailed fiscal histories in the IMF's (1982) Fiscal Policy in Twelve Small OECD Economies, the growth of real government spending in the years just after 1973 was largely "uncontrollable", in the sense that previous spending commitments based on pre-1973 economic assumptions were politically difficult to adjust for several years. As a result, when GDP growth fell after 1973, and government spending continued to increase, the ratio of $G$ to $Y$ rose sharply in most countries. The growth of taxes, on the other hand, slowed along side the slowdown in GDP, leaving the ratio of $T$ to $Y$ basically unchanged. ${ }^{4}$ With $G / Y$ increasing faster than the earlier trend,

4. Of course, the failure of $T / Y$ to $r i s e$ in parallel to $G / Y$ would be optimal to the extent that the rise in $G / Y$ is transitory. 
and $T / Y$ continuing along the earlier trend, large budget deficits naturally emerged.

This tendency towards a deflcte after the slowdown in growth was exacerbated for two additional reasons. First, many major areas of public spending (e.g. unemployment compensation, social welfare expenditure, early retirement benefits, job retraining, subsidies for alling firms) are Inherently countercyclical, so that portions of $G_{t}$ actually tend to $r$ ise automatically above prior forecasts when growth slows down below prior forecasts. This induced $r$ ise in $G_{t}$ tended to be greatest in economies where the growth slowdown was accompanied by a sharp rise in unemployment, $U_{t}$. since several kinds of soclal benefits are linked directly to the unemployed.

Another reason for Induced deficits was the intentional application by some countries of Keynesian aggregate demand policies in the face of the growth slowdown. The equilibrium model explicitly rejects the links of $G_{t}$ or $T_{t}$ to the level of output and employment via aggregate demand, but many governments did not (and many stfll do not) reject those links. Right or wrong, many governments are loath to ralse taxes or lower government spending during a recession.

As already noted, the large budget deficits that resulted from the growth slowdown and high unemployment can be viewed as consistent with the equilibrium model of budget deficits under the assumption that policymakers believed that $G / Y$ would fall back to the previous trend path. No doubt, most policymakers thought that at least part of the sharp jump in $G / Y$ after 1973 would be transitory, since it resulted from a growth slowdown and $r$ ise in unemployment that were themselves viewed as 
transitory for most of the 1970s. The unemployment rates, in particular, were expected (incorrectly, it turned out) to fall quickly back to the low levels before 1973, thus directly reducing a considerable part of the fiscal deficit.

The adverse shocks of slow growth and high unemployment were aggravated after 1979 by the rise in world real interest rates, which significantly and unexpectedly raised most governments' costs of debt servicing. One useful measure of the budgetary costs of higher interest rates is given by $b_{i t} * \Delta\left(r_{t}-n_{t}\right)$, where $\Delta\left(r_{t}-n_{t}\right)$ signifies the year-toyear change in the value of $r-n$. Between 1979 and 1981, this measure rose by several percent of GDP in most of the industrial economies, thereby greatly adding to the fiscal burden. This rise was particularly large, of course, in countries such as Belgium, Ireland, and Italy, that had already accumulated a large stock of debt. As with the unemployment increase and the growth slowdown, the effects of higher interest rates have turned out to be more persistent than many policymakers expected as of the early 1980 .

It would be useful at this point to present a full structural model of tax and spending adjustments, in order to quantify the effects of the growth slowdown, the rise in unemployment, and the higher interest rates, on the emergence of large budget deficits after 1973. The model could be used to evaluate the extent to which budget deficits have deviated from the levels predicted by the equilibrium model. Such a task is unfortunately beyond the scope of the present paper. At a minimum, it would require a rather sophisticated view about the ex ante expectations of economic growth, unemployment rates, and interest rates that were held 
by pollcymakers during the period 1973 to the present. Rather, we attempt something more modest, to describe the (basic) dynamic response of budget deficits to the major macroeconomic shocks in a semi-reduced-form equation.

We estimate a pooled cross-section time-series regression where the left-hand side variable is the annual deficit, measured as the change in the debt-GDP ratio, $\Delta b_{1 t}$. The basic explanatory variables are: (1) the lagged deficit, $\Delta b_{1, t-1} ;$ (2) the change in the unemployment rate, $\Delta U_{1 t}$; (3) the change in the GDP growth rate, denoted $\Delta n_{1 t} ;$ (4) the change in the real interest rate minus the growth rate, multiplied by the lagged debt. GDP ratio, $b_{1 t} \star \Delta\left(r_{t}-n_{t}\right)$; and (5) a political variable. $P_{1 t}$, described in the next section; and $(6)$ an error term, $v_{1 t}$. The basic structure of the pooled regression wodel is the following ( 1 denotes country, $t$ denotes time, and $\Delta x$ denotes the change in variable $x)^{5}$ :

$$
\begin{aligned}
\Delta b_{i t}= & a_{0}-a_{1} * \Delta b_{1, t-1}+a_{2} * \Delta U_{1 t}+a_{3} * \Delta n_{1 t}+ \\
& +a_{4} * \Delta r b_{i t}+a_{5} * p_{1 t}+v_{i t}
\end{aligned}
$$

According to our discussion, we expect that the deficit should be: a positive function, with a coefficient less than 1.0 , of the lagged deficit (to allow for any slow adjustment of budget deficits); a positive function of the change in the unemployment rate (since a rise in the unemployment rate raises $g_{t}$ above $g_{t}{ }^{p}$ in the short term); a negative

5. The exact definitions of the variables are given in the data appendix. 
function of the change in the GDP growth rate (since a rise in GDP growth lowers $g_{t}$ below $g_{t}{ }^{p}$ in the short term); a positive function of the change in the real interest rate, since a rise in $r-n$ directly raises $(r-n) b_{1 t}$ which if transitory should be accomodated by a temporary rise in the budget deficit.

The equation gives a rather successful account of the role of exogenous shocks in inducing the budget deficits in the industrial countries, as shown in Column 1 in Table 7. As expected, a rise in unemployment (denoted by DUB) raises the budget deficit; a rise in the debt-servicing cost (denoted by DRB) raises the budget deficit; an acceleration of GDP growth (denoted by DGR) lowers the budget deficit, indicating that the deceleration of GDP growth after 1973 contributed to the rise in budget deficits; finally, the lagged deficit enters with a coefficlent of about 0.70 , suggesting that about 70 percent of the lagged budget deficit persists to the next period. (Of course, without a full stochastic model for growth, unemployment, and interest rates, we can not easily judge whether the 0.70 is an appropriate speed of adjustment or not). Note that the variable measuring the slowdown in growth is the highly significant. Its magnitude suggests that each 1 percentage point slowdown in GDP growth Inftially raises the budget deficit relative to GDP by 0.45 percentage points. Since the average slowdown in growth was on the order of 3 percentage points, the impact effect was more than 1 percent of GDP.

Section IV. Political Institutions and Deflcit Adjustment 
The results in the previous section suggest that the shocks that hit the macroeconomles of the industrial countrles, particularly slower growth and higher unemployment after 1973, and higher real interest rates in the 1980s, all contributed to a jump in the budget deficits of the industrlal countries, partlcularly because the shocks were viewed to be transitory at the time that they hit. By the early 1980s, however, the growth slowdown and the rise in unemployment were widely understood to be highly persistent. At that point, some countries began to adjust to these shocks with strong flscal consolldation, whlle in other countrles, there continued to be many years of a steeply rising debt-GDP ratio. The alm of this section is to show that political factors help to account for rapid versus slow reductions of budget deficits. Our main finding is that multi-party coalition governments, especlally those with a short expected tenure, are poor at reducing budget deficits.

Note first from Table 3 the countrles that were successfully in stemming the rise in the net debt to GDP rat10, at least in the 1980 s. Eight countries were able to keep the rise in $b_{t}$ to below 10 percentage points between 1981 and 1985: the U.S., Germany, the U.K., Finland, France, Austria, Japan, and Norway. These countrles are characterized by a majortty parllamentary system (the U.K., Austria, Japan), a two-party coalition (Germany), or a presidential system (the U.S., Finland, France). Norway is the only multi-party coalltion government in the group. The other countries in Table 3, which failed to restrain the growth of public debt, are mostly characterized by proportional representation voting and multi-party coalitions (this is true in Italy, Belgium, Ireland, Netherlands, Sweden at times, and Denmark). 
The data also suggest upon closer inspection an asymetry in the link of political structures to budget deficits. Coalition governments are not inherently prone towards large deficits. During the 1960s, no major differences in budgetary behavior are evident between coalition governments and majority governments. Rather, it appears that coalition governments are prone to large deficits in circumstances of highly adverse macroeconomic shocks. We will attempt to explain this asymmetry later.

To set the empirical basis for the discussion, it is best to start with an empirical illustration of the basic linkages. We aim to show that an index variable measuring political structure can help to explain the evolution of budget deficits when added to the list of variables already included in equation (13). We create an index denoted $P_{i t}$ for country 1 at time $t$, that measures (in a simple way) the degree of political cohesion of the national government. The index is constructed as follows:

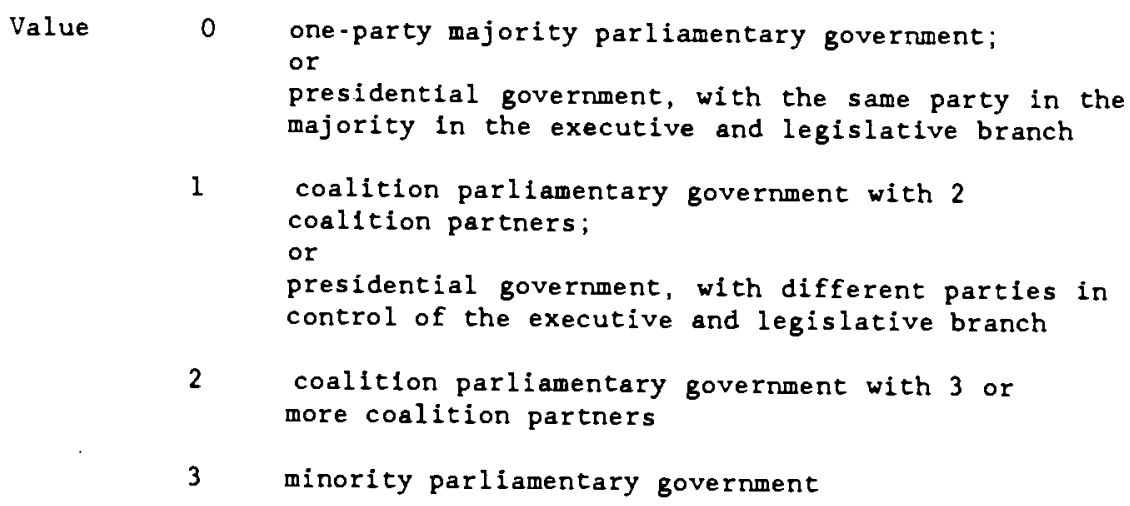

Details on the construction of the index for each particular country are given in the Data Appendix. 
In entering the political variable, we want to test the proposition that mult-party coalltion governments have a blas towards larger budget deficlts, but perhaps only during periods of macroeconomic stress. Therefore, we include both $p_{1 t}$ (termed POL in Table 7 ) and $p_{1 t}$ * $D$ (termed POLD), where $D$ is a dumy varlable equal to 0 during the rapid growth perlod 1960-74, and equal to 1 during 1975-85. We expect that the variable $P_{i t}$ * $D$ will be much more important than $P_{1 t} 1$ tself. We also Investigate an interaction term of the political varlable with the lagged deficit (termed DBYLPOL), on the view that the a divided political structure might reduce the speed of adjusting to an inherited level of the defic1t, $\Delta b_{1, t-1}$.

The results of the estimation are shown in columns 2 - 4 in Table 7. Several different versions of the regression are shown, Involving different ways of entering the political variable. The basic point is the following. The political variable always enters significantly when interacted with the dummy variable for 1975-86. The magnitude of the coefficlent on this variable, 0.005 , signifles that the difference cet, par, between a majority government and a minority government ( $p=0$ versus $p=3$ ), is 0.015 , or 1.5 percentage points of added budget deficlt per year. (Note that adding the dummy variable itself for 1975-86, in level form, to the regression does not change any results, and the dummy variable itself enters insigniflcantly). Note also that the interaction term of the political varfable with the lagged deficit (DBYLPOL) is of small magnitude and statistically insignificant. Why coalition governments find it hard to balance the budget ? 
Having given some empirical support to the role of the political variable, it is now time to offer some possible explanations of the observation. In our view, the essence of the budget problem for a coalition government results from three factors. First, the individual coalition partners in multi-party governments have distinctive interests and distinctive constituencies. There is no single uniform objective function for the varlous political parties in the government. There is likely to be a fundamental prisoner's dilemma with respect to budget cuts: all of the partners of the coalition may prefer comprehensive budget cuts to a continuation of large deficits, but each coalition partner may have the incentive to protect its particular part of the budget against the austerity measures. In the absence of strong coordination between members of the coalition to produce the "cooperative" outcome, the noncooperative solution of no-budget-cutting is quite likely to arise.

Second, individual coalition partners will often have enormous power to prevent a change in the status quo, though they will not typically have the power by themselves to implement a positive program of change. In other words, coalition members will have a veto against change. Even a very small party in a multi-party coalition can have enormous power by virtue of its ability to break up the government (formally, small parties may have very large Shapley values). Moreover, a coalition will typically divide responsibilities over various parts of the budget among the various members (this is certainly true in part by virtue of the distribution of ministerial positions among the parties). Third, the enforcement mechanisms among coalition partners to assure the cooperative outcome will often be very weak. 
Some of the polftical weaknesses of coalition governments are inherent in any legislative environment, as discussed by Weingast and Marshall (1988) in the context of policy in the U.S. Congress. These authors stress that trading votes in order to arrive at an efficlent overall budget Invarlably involve exchanges of benefits that are hard to monitor and hard to enforce. ${ }^{6}$ other problems of enforcement are particular to the case of multi-party coalition governments. Perhaps most important, because of the rapld turnover of multi-party coalition governments, the incentives for cooperation are reduced. As argued by Axelrod (1984), the enforceabllity of cooperation depends heavily on the repeated-play aspects of decision making. To the extent that the rapid turnover of governments reduces the time horizon for the repeated play among coalition members, their incentives to cooperate are reduced.

In these circumstances (w1th coalition members having distinct spending objectives, veto powers over parts of the budget, and an Inablity to make binding commltments with the other coalition members), adverse shocks to the economy, which require cuts in spending programs, can easily result in prolonged excesslve budget deficits. Even if all coalition members would favor an across-the-board cut in spending in order to reduce a large budget deficit, each coalition member may have the Incentive to block the spending cuts in lts ow area, while gladly

6. Weingast and Marshall stress that exchanges of votes will typically provide a stream of benefits for the traders that is noncontemporaneous ( $i . e$. one of the voters will benefit earlier than the others), making a vote-trading deal easier to renege on. Also vote trades are likely to be noncontemporaneous (one coalltion partner must support the other on the promise that the latter will support the former at a later date). 
supporting the spending cuts on other parts of the budget. The result is an obvious prisoner's dilemma: reducing the budget deficit is a public good among the coalition members.

Note that coalition governments might manage the budget quite well when overall macroeconomic circumstances are favorable. The point is simple. Individual coalition members may have the power to veto spending cuts, but not have the power to push through spending increases without the support of the other coalition members. Since the other coalition members will not generally have the incentive to support excessive spending increases, the coalition does not have a bias of generating excessive increases in overall spending, but only insufficient decreases in spending when spending cuts are needed. There is thus likely to be a fundamental asymetry between the budgetary responses to adverse macroeconomic shocks (which will produce excessive budget deficits) and to favorable macroeconomic shocks (which will result in appropriate overall levels of the deficit).

An additional and important point is made by Sir Karl Popper (1988), who stresses that the electorate can do little to discipline misbehaving parties in a system of multiple-party coalitions under proportional representation voting. It might be supposed, for example, that political parties will cooperate with each other because of the glare of bad publicity, and subsequent electoral punishment, for parties that refuse to cooperate. In Popper's view, elections cannot effectively punish individual parties for the failures of coalition governments in a PR system, with the result that the critical electoral mechanism for enforcing good behavior is rendered ineffective. 
Popper puts the 1ssue this way.

While proportional representation 1 s based on the 1 dea that the influence of a party should be proportional to its voting power, a coalition government means, more often than not, that small parties can exercise a disproportionately great -. and often decisive.influence, on the formation of a government and on its resignation, and so on all its decisions. Most important of all, it means the decay of responsibility. For in a coalition government there is reduced responsibility for all the partners in the coalition.

Proportional representation - . and the greater number of parties as a result thereof - - may therefore have a detrimental effect on the decisive issue of how to get rid of a government by voting it out of office, for instance in a parliamentary election. The voters are led to expect that perhaps none of the parties will obtain an absolute majority. With this expectation in their minds, the people hardly vote against any of the parties. As a result, on election day none of the parties is dismissed, none is convicted. Accordingly, nobody looks on election day as a day of judgement...

The loss of 58 or 108 of votes by one or other of the parties is not seen by the voters as a verdict of "gullty". They look at $1 t$, rather, as a temporary fluctuation in popularity. In time, the people become used to the idea that none of the political parties or their leaders can really be made accountable for their decisions which may have been forced on them by necessity to form a coalition.

of course, all of these problems of coordinating austerity measures are present, to some extent, in all types of democratic goverments. The U.S. Congress is in some ways like a multi-party coalition government, given the enormous varlety of reglonal, sectoral, and other special interests that are organized into powerful factions in the Congress. The speciflc party disclpline of the Democrats and Republicans is often very low. It is our assumption, however, that the problems are typically exacerbated by the need to mesh the interests of many parties in a single government. An individual majority party has many crucial powers and constraints that allow it to come closer to enforcing "good behavior". 
To further illuminate the underlying mechanisms behind our findings, and to bolster the case that they in fact reflect actual phenomena, we examine one historical case in some detall, a case that is as close to a pure laboratory experiment as we could find. After World War II until 1958, the French political regime (known as the Fourth Republic) was a parliamentary system with mult-party coalition governments. The political system was widely regarded as a fallure. In 1958, de Gaulle became Prime Minister and was given extraordinary powers. At the end of the year, a new constitution was voted (the Fifth Republic), which created a presidential system. We examine the budgetary implications of that change in political regime. I

As a reaction to the authoritarlan regimes of the World War II period, the Fourth Republic was formed in 1946 in the form of a proportional representation (PR) political system. The PR electoral laws led to a very fractionalized party structure and the need to form coalition governments. The resulting governments were multi-party coalitions of the center and right, with very different Ideologies, and economic and political agendas. The instability of the resulting governments was notorlous: during 1946-1958, there were 26 different governments, with an average tenure of 6 months!

The rivalries between the parties led to an ineffectual budget process, leading to the term "Immobilisme" to characterize the political system and the economic management. As seen in Table 8 , large budget deficits resulted from the lack of cohesion of the various coalition

7. This section relies heavily on Edgar S. Furniss, Jr., France, Troubled Ally: De Gaulle's herltage and prospects, New York: Frederick A. Praeger, 1960, for the Council on Forelgn Relations. 
governments, which were subjected to pressures for increased spending on patronage and local projects. The war in Vietnam was a major source of expenditure until 1954, but the growth of spending and the size of the deficits remained very large even after the end of the French military involvement in Vietnam (the defense burden did remain large, however, because of the deteriorating situation in Algeria).

Furniss (1960) describes the budgetary process in the Fourth

Republic as follows:

Getting the cabinet to agree on a budget was frequently painful, but this was only the beginning of a French premier's ordeal. He had still to fight the budget, item by item, through any number of National Assembly committees, beating back amendments and even complete substitutes, almost all of which would seek to increase expenditures. Finally if he had not fallen on some other issue, he had to maneuver for a series of favorable votes in the Assembly, on each of which his cabinet's life was at stake. (pp. 157-158).

The budget ordeal in 1958, on the eve of the collapse of the Fourth

Republic, is symptomatic:

Bourges-Maunoury fell on the Algerian question before his budget could come to a vote. Stepping up from Finance Minister to Premier, Gaillard tried to push through the same budget on the theory that deputies will sometimes accept disagreeable policies after a premier has first been sacrificed. As his shaky government tottered towards the abyss, pressures to restore the cuts rose rather than diminished. By the time Pflimlin appeared on the scene, the Right, having caused the collapse of three governments within the year, was all set to attack that portion of the budget allocated to national defense.. . In June 1958, when de Gaulle assumed power, the budget still had not been voted ( $p$. 158)

The Fourth Republic disintegrated in 1958 submerged under the mounting political, economic and diplomatic crises of the system. De Gaulle came to power in June 1958 with the power to rule by decree for six months. A new Constitution was written, approved by referendum in September, and made effective in October. De Gaulle came into power as 
president in January 1959. De Gaulle immediately attacked the budget deficlt, completing the 1958 budget by decree. In early 1959, he announced an emergency program of "truth and austerity" aimed at cutting drastically the budget deficlt. 250 different economic ordinances were issued by decree between January and February 1959. The program Included both increases in revenues and reductions in expenditures. ${ }^{8}$ As shown in Table 8 , the budget deficlt that had averaged 4.7 percent of GDP per year during 1950-58, and was 4.9 percent of GDP in 1957, fell to 2.8 percent in 1958, 2.4 percent of GDP in 1959, and 1.4 percent of GDP in 1960 and 1961. In 1965, the budget was in balance, and the budget was in substantial surplus during 1970 and $1972-74$.

We have attempted to test statistically for the effect of the political transition by estimating a budget deficit equation for France over the post-war period. The main reason for the estimating a regression equation is to control for other factors (particularly temporary shifts in government expenditure) that might have been influencing the size of the budget deficits during the transition period. The most important set of factors includes the high and declining level of military spending in the 1950s (tied to the French Indochina War, the Algerian War, the NaTo

8. On the revenue side 313 billion francs were raised with increased tax rates for corporate profits, higher tax rates on personal income at all levels, increases of taxes on tobacco, alcohol, wine and distilled spirits by between 20 percent and 100 percent; greater levies on intermediate and final goods. On the spending side, a wide range of expenditures and subsidies were abolished or reduced, with savings of 245 billion francs. 
buildup) (MIL), post-war reconstruction expenditures (WARDAM) and a dummy variable for the Fourth Republic. The basic equation is as follows: 9

\begin{tabular}{|c|c|c|c|c|c|}
\hline 10le. 194 & $0^{2}$ & $=0.83$ & D.W. & $=1.27$ & \\
\hline $\begin{array}{l}-0.49 \\
(0.74)\end{array}$ & $\begin{array}{r}+0.28 \mathrm{MIL} \\
(2.54)\end{array}$ & $\begin{array}{r}0.48 \\
(1.30)\end{array}$ & WARDAM & $\begin{array}{c}-0.67 \text { USAID } \\
(2.33)\end{array}$ & $\begin{array}{l}+2.91 \text { FOLRREP } \\
(3.43)\end{array}$ \\
\hline
\end{tabular}

Sample: $1950-1972 \quad R^{2}=0.92 \quad$ D.W. $=1.55$

$\mathrm{DEF}=\underset{(4.03)}{-2.05}+\underset{(6.53)}{0.60 \mathrm{MIL}}+\underset{(1.09)}{0.28 \text { WARDAM }}-\underset{(4.59)}{0.88}$ USAID $+\underset{(3.48)}{2.23 \text { FOURREP }}$

The estimated equations show the significant role of temporary military expenditures (MIL) in affecting the French fiscal deficits during the period considered but also confirm the structural break in the deficits between the Fourth and the Fifth Republic: the Fourth Republic dummy is significant and its value suggests an average reduction in fiscal deficits of over 28 of GDP between the Fourth and the Fifth Republic.

Many other possible case studies come to mind in addition to the French experience. We hope to examine some of these other cases in more detail in later work. Some obviously fruitful cases for political analysis include: Italy, with decades of chronically weak coalition goverments: Belgium, with weak coalition governments with parties that are divided along linguistic and geographical lines as well as ideological lines.; and the U.S., with divided responsibility between Republican

9. The definitions of the variables, and the data sources, are as follows: DEF - Central Government Budget Deficit; MIL = Total Military Expenditures; WARDAM = Expenditures for War Damages; USAID = Grants from the United States; FOURREP - Dummy variable equal to 1 during the Fourth Republic and 0 otherwise. All budget data are expressed as a share of GDP and are taken from: Ministere de L'Economie et des Finances Statistiques Etudes Financieres, Special Issue, 1974. 
control of the White House during the 1980s, and Democratic Party control of one or both houses of the Congress during the same period. On the other side are fascinating case studies of successful budget deficit reduction in the $1980 \mathrm{~s}$. Surely the most impressive case in this regard is Japan, where the ruling Liberal Democratic Party -- with its unbroken majority control - has been able to announce, implement, and follow through on a multi-year plan of deficit reduction that was begun in 1981 .

Part IV. Conclusions

Our conclusions may be succinctly stated. We have found little evidence to support the equilibrlum model of fiscal policy, which assumes that taxes are set over time in order to minimize the excess burden of taxation. Tax rates do not seem to be smoothed, and budget deficits in many countries appear to be too large to explain by appeal to transitory increases in government spending.

In most of the countries, deficits were small before the slowdown in OECD growth after 1973. During 1960-73, most of the OECD economies experienced falling or very gently rising debt-GDP ratios. With the growth slowdown and with the rise in unemployment, the ratio of government spending to GDP increased markedly and beyond expectation, producing significant budget deficits, and sharply rising ratios of debt to GDP in several countries. This process was greatly exacerbated by the sharp rise in real interest rates after 1979 . To the extent that the bulge in the ratio of $G$ to GDP was temporary, it would be appropriate to run budget deficits during the period in which $G / Y$ falls back to more normal levels. It appears, however, that the size of the actual deficits 
in most of the countries is too large to be accounted for by this transitional phenomenon.

We suggest that in several countries, the slow rate at which the post-'73 fiscal deficits were reduced resulted from the difficulties of political management in coalition governments. Durling the period 1975-85, there is a clear tendency for larger deficits in weaker governments, where weakness is indicated by a short average tenure of government and by the presence of many political parties in the coalition. In the final section of the paper we illustrate the problems of budgetary management with coalition governments, first in two case studies, and then in a simple theoretical model. The greatest difficulties appear to arise because small coalition partners have veto power over changes in the status quo. 


\section{References}

Alesina, A. (1986) "Macroeconomics Policy in a Two-Party System as a Repeated Game", Quarterly Journal of Economics, 102, 651-678.

(1986) "Macroeconomfc Policy in a Two-Party System", Unpublished Ph.D. Thesis, Harvard University.

and G. Tabelini (1987) "A Positive Theory of Fiscal Deficits and Government Debt in a Democracy", mimeo.

Alesina, A. and J. Sachs (1988) "Political Parties and the Business Cycle in the United States, 1948-1984", Journal of Money Credit and Banking, February, 63-82,

Aschauer, D.(1988) "The Equilibrium Approach to Fiscal Policy", Journal of Money, Credit and Banking. February, 41-62.

Axelrod, R. (1984) The Evolution of Cooperation.

Barro, R. (1979) "On the Determination of Public Debt", Journal of Political Economy, 87, October, $940-971$.

(1981) "Output Effects of Government Purchases", Journal of Political Economy, 89, December, 1086-1121. 
(1985) "Government Spending, Interest Rates, Prices and budget Deficits in the United Kingdow, 1730-1918", Work1ng Paper No.l Rochester Center for Economic Research, March.

and D. Gordon (1983 a) "Rules, Discretion and Reputation in a model of Monetary Policy", Journal of monetary Economics, 12, July, 101-121.

$(1983$ b) "A Positive Theory of Monetary Pollcy in a

Natural Rate Model", Journal of Polltical Economy, 91, August, 589-610.

Blondal, G. (1986) Fiscal Polfcy in the Smaller Industrial Countries: 1972 1982, International Monetary Fund, Washington, D.C..

Buchanan, J., C. Rowley and R. Tollison (1986) Deflclts, Basil Blackwell.

Canarella, G. and N. Garston (1983) "Monetary and Public Debt Shocks", Jaurnal of Money. Credit and Banking, May, 199-211.

Furniss, E. (1960) Erance. Troubled Ally: De Gaulle's Heritage and Prospects, New York, Praeger, for the Council on forelgn Relations.

Havrilesky, T. (1988) "Monetary Policy Signalling from the Administration to the Federal Reserve", Journal of Money, Credit and Banking, February, 83101. 
Kydland, F. and E. Prescott (1977) "Rules Rather Than Discretion: The Inconsistency of Optimal Plans", Journal of Political Economy, 85, June, $473 \cdot 93$.

International Monetary Fund (1982) Fiscal Policy in the Smaller Industrial Countries: $1972-1982$, Washington, D.C.

Mankiw, G. (1987) "The Optimal Collection of Seignorage: Theory and Evidence", Journal of Monetary Economics, $20,327.342$.

Poterba, J. and J. Rotemberg (1988) "Inflation and Taxation with Optimizing Governments", NBER Working Paper No. 2567 (Apri1).

Popper, K. (1988) "The Open Society and Its Enemies Revisited", Ihe Economist, April 23, $19-22$.

Powe11, G. B. (1982) Contemporary Democracies: Participation, Stability and Violence, Harvard University Press, Cambridge.

Sahasakul, C. (1986) "The U.S. Evidence on Optimal Taxation over Time", Journal of Monetary Economics, 18, November, 251-275,

Saunders, P. and F. Klau (1985) "The Role of the Public Sector: Causes and Consequences of the Growth of Government", OECD Economic Studies, spring. 
Weingast, B. and $W$. Marshall (1988) "The Industrial Organization of Congress; or, Why Leglslatures, Like Flros, Are Not Organlzed as Markets", Journal of Political Economy, 96, February, 132-163. 


\section{Data Appendix}

Government Expenditures: General government expenditures including interest payments on net debt corrected for inflation and growth. Data on expenditures from OECD National Income Accounts (OECD NIA).

Governments Revenues: General government revenues from OECD NIA.

GDP: Gross Domestic Output from OECD NIA.

Government Debt: General Government Net Debt. OECD data.

Inflation Rate: Base on GDP deflators from OECD NIA. For regressions in Table 5 CPI inflation rates from IMF-IFS are used.

Unemployment Rates: Standardized Unemployment Rates. OECD Main Economic Indicators.

Average Tenure of a government: Varlable created with data on national governments in "Political Parties of Europe" ed. by $V$. McHale and S. Skowronski, Greenwood Press, 1983; "The Europa Yearbook", 1987.

BY : Net debt to GDP ratio.

DBY : Change in net debt to GDP ratio.

DBYL: $\operatorname{DBY}(t-1)$.

DGR : Change in GDP growth rate - Growth in GDP at time $t$ minus an average of GDP growth rates in the previous three years.

DUB : Change in the unemployment rate - Unemployment rate at time $t$ minus an average of unemployment rates in the previous eight years.

POL : Index of Political Cohesion. Described in detail below.

POLD: POL multiplied by a dumny varlable for the 1975-1985 period.

DBYLPOL: POL * DBYL. 
DUJAP : DUB times a dummy variable equal to 1 for Japan.

$D R B:=\Delta\left(r^{e}-n\right) B Y(t-1)$ where $r^{e}-i \cdot \pi^{e} ; i$ - interest payments on government debt divided by gross general government debt; $\pi^{\mathbf{e}}$ - welghted average of inflation rates at time $t$ and 3 lagged perlods: $n$ - welghted average of GDP growth rates at time $t$ and 3 lagged periods.

Description of POL variable.

POL : Index of the Political Cohesion of the National Government.

\begin{tabular}{|c|c|c|c|c|c|c|c|}
\hline & $\begin{array}{l}\text { United } \\
\text { States }\end{array}$ & France & Germany & Japan & $\begin{array}{l}\text { United } \\
\text { Kingdom }\end{array}$ & Austria & Belgium \\
\hline 1960 & 0 & 1 & 1 & 0 & 0 & 1 & 1 \\
\hline 1961 & 0 & 1 & 1 & 0 & 0 & 1 & 1 \\
\hline 1962 & 0 & 1 & 1 & 0 & 0 & 1 & 1 \\
\hline 1963 & 0 & 1 & 1 & 0 & 0 & 1 & 1 \\
\hline 1964 & 0 & 1 & 1 & 0 & 0 & 1 & 1 \\
\hline 1965 & 0 & 1 & 1 & 0 & 0 & 1 & 1 \\
\hline 1966 & 0 & 1 & 1 & 0 & 0 & 0 & 1 \\
\hline 1967 & 0 & 1 & 1 & 0 & 0 & 0 & 1 \\
\hline 1968 & 0 & 1 & 1 & 0 & 0 & 0 & 1 \\
\hline 1969 & 1 & 1 & 1 & 0 & 0 & 0 & 1 \\
\hline 1970 & 1 & 1 & 1 & 0 & 0 & 0 & 1 \\
\hline 1971 & 1 & 1 & 1 & 0 & 0 & 0 & 1 \\
\hline 1972 & 1 & 1 & 1 & 0 & 0 & 0 & 1 \\
\hline 1973 & 1 & 1 & 1 & 0 & 0 & 0 & 2 \\
\hline 1974 & 1 & 1 & 1 & 0 & 0 & 0 & 2 \\
\hline 1975 & 1 & 1 & 1 & 0 & 0 & 0 & 2 \\
\hline 1976 & 1 & 1 & 1 & 0 & 0 & 0 & 2 \\
\hline 1977 & 0 & 1 & 1 & 0 & 0 & 0 & 2 \\
\hline 1978 & 0 & 1 & 1 & 0 & 0 & 0 & 2 \\
\hline 1979 & 0 & 1 & 1 & 0 & 0 & 0 & 2 \\
\hline 1980 & 0 & 1 & 1 & 0 & 0 & 0 & 2 \\
\hline 1981 & 1 & 1 & 1 & 0 & 0 & 0 & 2 \\
\hline 1982 & 1 & 1 & 1 & 0 & 0 & 0 & 2 \\
\hline 1983 & 1 & 1 & 1 & 0 & 0 & 1 & 2 \\
\hline 1984 & 1 & 1 & 1 & 0 & 0 & 1 & 2 \\
\hline 1985 & 1 & 1 & 1 & 0 & 0 & 1 & 2 \\
\hline
\end{tabular}




$\begin{array}{llllllll}1960 & 1 & 1 & 3 & 2 & 0 & 0 & 0 \\ 1961 & 1 & 1 & 3 & 2 & 0 & 0 & 0 \\ 1962 & 1 & 1 & 2 & 2 & 0 & 0 & 0 \\ 1963 & 1 & 1 & 3 & 2 & 0 & 0 & 0 \\ 1964 & 0 & 1 & 2 & 2 & 0 & 0 & 0 \\ 1965 & 0 & 1 & 2 & 2 & 2 & 0 & 0 \\ 1966 & 0 & 1 & 2 & 1 & 2 & 0 & 0 \\ 1967 & 0 & 1 & 2 & 2 & 2 & 0 & 0 \\ 1968 & 2 & 1 & 3 & 2 & 2 & 0 & 0 \\ 1969 & 2 & 1 & 1 & 2 & 2 & 0 & 0 \\ 1970 & 2 & 1 & 2 & 2 & 2 & 0 & 0 \\ 1971 & 0 & 1 & 2 & 2 & 0 & 0 & 0 \\ 1972 & 3 & 1 & 3 & 2 & 2 & 0 & 0 \\ 1973 & 3 & 1 & 2 & 2 & 0 & 0 & 1 \\ 1974 & 3 & 1 & 3 & 2 & 0 & 0 & 1 \\ 1975 & 3 & 1 & 3 & 2 & 0 & 0 & 1 \\ 1976 & 3 & 1 & 3 & 2 & 0 & 2 & 1 \\ 1977 & 3 & 1 & 3 & 2 & 0 & 2 & 1 \\ 1978 & 1 & 1 & 3 & 2 & 0 & 3 & 0 \\ 1979 & 3 & 1 & 3 & 2 & 0 & 2 & 0 \\ 1980 & 3 & 1 & 2 & 2 & 0 & 2 & 0 \\ 1981 & 3 & 1 & 2 & 2 & 3 & 3 & 1 \\ 1982 & 3 & 1 & 2 & 3 & 2 & 3 & 1 \\ 1983 & 3 & 1 & 2 & 2 & 2 & 1 & 1 \\ 1984 & 2 & 1 & 2 & 2 & 2 & 1 & 1 \\ 1985 & 2 & 1 & 2 & 2 & 2 & 1 & 1\end{array}$

Source: Data on national governments in "Political Parties of Europe" ed. by V. McHale and S. Skowronski, Greenwood Press, 1983; "The Europa Yearbook", 1987.

Note: France and Finland are given a score of 1 for being presidential regimes where coalition governments are usually formed. The United States is given a score of 1 when there is divided power (different parties in control of the executive and legislative branch). 
Table 1. Basic Statistics on the General Government Accounts.

$\begin{array}{lll}\text { Country } & \text { Expenditures Revenues Annual } & \text { Level of } \\ & \text { Change in Net Debt } \\ & \text { Net Debt (in of GDP) }\end{array}$

\section{Austria}

$1961-1964$

$1965-1969$

$1971-1974$

$1975-1979$

$1980-1985$

37.6

44.7

46.9

Belgium

$1961-1964$

1965-1969

$1970-1974$

1975-1979

1980-1985

\section{Canada}

$1961-1964$

1965-1969

1970-1974

1975-1979

$1980-1985$

Denmark

$1961-1964$

1965-1969

1971-1974

1975-1979

1980-1985

Finland

1961-1964

1965-1969

$1971-1974$

1975-1979

1980-1985
24.1

29.0

31.9

42.2

48.5

23.7

25.8

30.5

33.6

37.0

29.2

32.8

36.1

41.5

44.8

$-3.34$

$-1.94$

$-2.33$

2.84

8.25

68.9

59.2

47.5

61.7

111.2

35.9

47.3 
France

$1961-1964$

1965-1969

1970-1974

$1975-1979$

$1980-1985$

Germany

$1961-1964$

1965-1969

$1970=1974$

1975.1979

$1980-1985$

Ireland

$1961-1964$

1965-1969

$1971-1974$

1975-1979

1980-1985

Italy

1961- 1964

1965-1969

$1970-1974$

$1975-1979$

1980-1985
33.3

36.2

35.9

41.2

46.8
36.9

38.7

38.7

42.2

47.2
$-2.77$

$-0.91$

$-0.93$

0.20

1. 16
18.0

13.4

8.7

9.7

16.8
35.1

37.0

40.0

45.8

45.5
36.4

37.0

40.0

44.1

45,1
$-0.38$

1.17

0.84

3.23

1.77
$-14.8$

$-8.9$

$-4.7$

11. 5

22. 2

34.1

34.7

0.50

37.1

35.2

5. 56

42.2

6.35

64.9

41.6

103.0

24.7

36.7

49.2

30.0

2.00

2. 50

30.6

2.90

63.7

43.0

34.0

5.43

96.3

Japan

1961- 1965

1966-1969

1970-1974

1975-1979

42.0

17.0

21.3

26.7

28.8
19.4

22.1

24.6

29.6
0.02

0.03

4.04

1. 94
-

$-5.5$

$-5.3$

14.9

26.5

\section{Norway}

$1961-1964$

1965-1969

1971-1974

1975-1979

41.4

$48: 2$

$-1.08$

51.0

3. 72

53.9

$-5.96$

$-1.8$

16.8

43.8

$-19.0$ 


\section{Netherlands}

1961-1964

1965-1969

1971.1974

1975.1979

1980-1985

Sweden

$1961 \cdot 1964$

1965-1969

1971-1974

1975.1979

1980-1985

United States

$1961-1964$

$1965-1969$

1970-1974

$1975-1979$

$1980-1985$

United Kingdom
23. 9

24.8

26. 9

27.6

30.5
26.4

27.6

29.2

29.6

31.0
.1 .65

$-2.01$

$-1.20$

$-0.49$

1.22
19.0

21.8

41.6
38.3

28.3

22.2

19.8

27.1

$\begin{array}{rrrrr}1961-1964 & 25.9 & 31.7 & -6.39 & 102.6 \\ 1965-1969 & 30.6 & 36.1 & -4.09 & 82.1 \\ 1970-1974 & 31.0 & 39.0 & -5.44 & 54.9 \\ 1975-1979 & 33.1 & 39.8 & -1.24 & 48.7 \\ 1980-1985 & 41.0 & 43.1 & -0.21 & 47.4\end{array}$

Source: OECD National Income Accounts for expenditures and revenues. OECD data for net public debt. 
Table 2. Basic data on deficlts and governments. 1975-1985.

\begin{tabular}{|c|c|c|c|}
\hline Country & $\begin{array}{l}\text { Change in Debt/GDP } \\
\text { Ratio (per year) } \\
\text { (in percent) }\end{array}$ & $\begin{array}{l}\text { Average Tenure } \\
\text { of Governments } \\
\text { (In years) }\end{array}$ & $\begin{array}{l}\text { Typical Form of the } \\
\text { Political Regime }\end{array}$ \\
\hline
\end{tabular}

\begin{tabular}{|c|c|c|c|}
\hline Belglum & 6.16 & 1.0 & $\begin{array}{l}\text { Multi-Party } \\
\text { Coalitlons }\end{array}$ \\
\hline Ireland & 5.80 & 2.2 & Small Coalitions \\
\hline Denmark & 4.53 & 1.5 & $\begin{array}{l}\text { Multi-Party } \\
\text { Coalitions }\end{array}$ \\
\hline Sweden & 4.41 & 1.5 & Small Coalitions \\
\hline Italy & 3.65 & 1.2 & $\begin{array}{l}\text { Multi-Party } \\
\text { Coalition }\end{array}$ \\
\hline Japan & 2.86 & 11.0 & $\begin{array}{l}\text { Single Party } \\
\text { Majority }\end{array}$ \\
\hline Austria & 2.34 & 5.5 & $\begin{array}{l}\text { Single Party } \\
\text { Majority }\end{array}$ \\
\hline Netherlands & 2.19 & 1.8 & $\begin{array}{l}\text { Multi-Party } \\
\text { Coalitions }\end{array}$ \\
\hline Germany & 2.12 & 5.5 & Two-Party Coalitions \\
\hline Finland & 1.00 & 1.5 & $\begin{array}{l}\text { Presidential with } \\
\text { Coalition Governments }\end{array}$ \\
\hline France & 0.57 & 3.6 & $\begin{array}{l}\text { Presidential with } \\
\text { Coalition Governments }\end{array}$ \\
\hline United States & 0.25 & 3.6 & $\begin{array}{l}\text { Presidential with } \\
\text { Divided Legislature }\end{array}$ \\
\hline United Kingdom & -0.97 & 5.5 & $\begin{array}{l}\text { Single Party } \\
\text { Majority }\end{array}$ \\
\hline Norway & -1.97 & 3.6 & $\begin{array}{l}\text { Single Party Majority } \\
\text { or Small Coalitions }\end{array}$ \\
\hline
\end{tabular}


Table 3. General Government Net Debt to GDP ratio. 15 OECD countries I960-1986

\begin{tabular}{rrrrrrrrr} 
YEAR & \multicolumn{1}{l}{ US } & GERMANY & FRANCE & \multicolumn{1}{l}{ UK } & ITALY & CANADA & BELGIUM & IRELAND \\
& & & & & & & & \\
\hline 1960 & 45.0 & -13.2 & 29.1 & 123.2 & na & na & 82.3 & na \\
1961 & 44.7 & -15.4 & 25.8 & 120.9 & na & 21.8 & 80.0 & na \\
1962 & 42.5 & -15.5 & 22.2 & 116.1 & na & 20.7 & 76.8 & na \\
1963 & 40.4 & -13.3 & 19.9 & 109.2 & na & 20.9 & 74.5 & na \\
1964 & 38.3 & -14.8 & 18.0 & 102.6 & 26.7 & 18.9 & 68.9 & na \\
1965 & 35.3 & -12.8 & 16.1 & 96.7 & 30.2 & 16.7 & 66.6 & na \\
1966 & 32.5 & -11.9 & 15.0 & 92.5 & 34.2 & 15.3 & 65.1 & na \\
1967 & 32.4 & -10.1 & 14.6 & 92.4 & 34.1 & 15.2 & 63.3 & na \\
1968 & 30.7 & -8.8 & 14.8 & 86.8 & 36.9 & 13.2 & 62.2 & na \\
1969 & 28.3 & -8.9 & 13.4 & 82.1 & 36.7 & 9.2 & 59.2 & na \\
1970 & 27.8 & -8.1 & 11.4 & 74.8 & 39.1 & 6.1 & 55.5 & 35.7 \\
1971 & 27.9 & -7.1 & 11.0 & 70.1 & 43.9 & 4.6 & 54.6 & 35.1 \\
1972 & 25.8 & -5.7 & 9.1 & 65.3 & 49.9 & 4.2 & 52.6 & 33.2 \\
1973 & 23.0 & -6.7 & 8.3 & 57.9 & 52.0 & 2.6 & 50.9 & 32.0 \\
1974 & 22.2 & -4.7 & 8.7 & 54.9 & 49.2 & 1.1 & 47.5 & 37.1 \\
1975 & 24.6 & 1.0 & 11.1 & 57.2 & 59.8 & 4.3 & 49.8 & 45.9 \\
1976 & 24.4 & 4.6 & 10.9 & 56.0 & 60.8 & 5.2 & 50.1 & 51.6 \\
1977 & 23.3 & 7.0 & 10.2 & 55.7 & 60.7 & 7.5 & 53.7 & 50.6 \\
1978 & 21.3 & 9.4 & 10.2 & 53.4 & 63.8 & 10.3 & 57.5 & 56.3 \\
1979 & 19.8 & 11.5 & 9.7 & 48.7 & 63.7 & 10.9 & 61.7 & 64.9 \\
1980 & 19.8 & 14.4 & 9.1 & 48.1 & 61.8 & 11.6 & 69.0 & 69.4 \\
1981 & 19.1 & 17.5 & 9.9 & 47.2 & 66.8 & 10.8 & 81.5 & 75.1 \\
1982 & 21.7 & 19.8 & 11.3 & 46.6 & 73.4 & 17.0 & 89.2 & 81.2 \\
1983 & 24.4 & 21.4 & 13.4 & 47.2 & 80.6 & 20.5 & 99.4 & 88.0 \\
1984 & 25.4 & 21.8 & 15.2 & 48.9 & 87.8 & 24.9 & 104.3 & 94.6 \\
1985 & 27.1 & 22.2 & 16.8 & 47.4 & 96.3 & 30.5 & 111.2 & 103.0 \\
1986 & 28.7 & 22.1 & 18.2 & 46.5 & 99.2 & 33.7 & 113.3 & na
\end{tabular}




\begin{tabular}{lrllllllr} 
YEAR & FINLAND & \multicolumn{2}{c}{ AUSTRIA NETHERL } & SWEDEN & NORWAY & JAPAN & DENMARK \\
& & & & & & & \\
1960 & na & na & na & na & na & na & na \\
1961 & na & na & na & na & na & na & na \\
1962 & na & na & na & na & na & na & na \\
1963 & na & na & na & na & na & na & na \\
1964 & na & na & na & na & na & na & na \\
1965 & na & na & na & na & na & -5.6 & na \\
1966 & na & na & na & na & na & -5.6 & na \\
1967 & na & na & na & na & na & -7.0 & na \\
1968 & na & na & na & na & na & -6.3 & na \\
1969 & na & na & na & na & na & -5.5 & na \\
1970 & -5.0 & 19.4 & 28.9 & -24.0 & 2.5 & -6.5 & -2.8 \\
1971 & -7.3 & 18.2 & 27.7 & -27.5 & 2.6 & -7.2 & -5.9 \\
1972 & -8.0 & 17.5 & 24.5 & -29.5 & 0.6 & -6.5 & -9.0 \\
1973 & -10.7 & 17.5 & 21.0 & -31.1 & -1.4 & -6.1 & -12.2 \\
1974 & -10.5 & 17.6 & 19.0 & -30.1 & -1.8 & -5.3 & -13.6 \\
1975 & -9.5 & 23.9 & 19.7 & -28.7 & 0.7 & -2.1 & -10.1 \\
1976 & -10.5 & 27.4 & 20.3 & -29.7 & 3.5 & 1.9 & -7.7 \\
1977 & -9.9 & 30.0 & 19.2 & -28.8 & 9.5 & 5.5 & -5.0 \\
1978 & -8.3 & 33.8 & 20.0 & -25.3 & 14.0 & 11.3 & -2.1 \\
1979 & -6.8 & 35.9 & 21.8 & -19.8 & 16.8 & 14.9 & 1.8 \\
1980 & -6.0 & 37.1 & 24.9 & -13.5 & 6.9 & 17.3 & 7.2 \\
1981 & -4.6 & 39.2 & 27.3 & -5.2 & 3.9 & 20.6 & 16.5 \\
1982 & -1.8 & 41.6 & 31.3 & 4.4 & 1.3 & 23.2 & 26.3 \\
1983 & 0.4 & 46.4 & 36.5 & 10.5 & -2.4 & 26.2 & 34.1 \\
1984 & 0.7 & 47.8 & 38.3 & 12.6 & -9.6 & 27.0 & 37.5 \\
1985 & 0.6 & 47.3 & 41.6 & 15.4 & -19.0 & 26.5 & 35.2 \\
1986 & 0.0 & 47.7 & 46.0 & 14.5 & -24.4 & 26.3 & 28.4 \\
& & -9.6 & & & & & &
\end{tabular}

Source: OECD Data. 
Table 4. General Government Revenues as a share of GDP. 1960-1965.

\begin{tabular}{|c|c|c|c|c|c|c|c|}
\hline Year & $\begin{array}{l}\text { United } \\
\text { States }\end{array}$ & Japan & Germany & France & $\begin{array}{l}\text { United } \\
\text { Kingdom }\end{array}$ & Italy & Canada \\
\hline 1960 & 0.263 & NA & 0.350 & 0.349 & 0.300 & 0.288 & 0.260 \\
\hline 1961 & 0.263 & NA & 0.362 & 0.362 & 0.312 & 0.282 & 0.263 \\
\hline 1962 & 0.265 & NA & 0.365 & 0.363 & 0.328 & 0.291 & 0.266 \\
\hline 1963 & 0.270 & $\mathrm{NA}$ & 0.367 & 0.371 & 0.314 & 0.295 & 0.263 \\
\hline 1964 & 0.259 & NA & 0.362 & 0.380 & 0.315 & 0.306 & 0.272 \\
\hline 1965 & 0.259 & 0.197 & 0.355 & 0.384 & 0.331 & 0.301 & 0.276 \\
\hline 1966 & 0.267 & 0.191 & 0.361 & 0.384 & 0.343 & 0.301 & 0.288 \\
\hline 1967 & 0.271 & 0.193 & 0.367 & 0.382 & 0.362 & 0.310 & 0.303 \\
\hline 1968 & 0.287 & 0.196 & 0.378 & 0.388 & 0.376 & 0.316 & 0.317 \\
\hline 1969 & 0.299 & 0.196 & 0.393 & 0.398 & 0.395 & 0.307 & 0.337 \\
\hline 1970 & 0.289 & 0.207 & 0.383 & 0.390 & 0.412 & 0.304 & 0.342 \\
\hline 1971 & 0.282 & 0.216 & 0.394 & 0.383 & 0.391 & 0.311 & 0.347 \\
\hline 1972 & 0.293 & 0.215 & 0.398 & 0.382 & 0.375 & 0.309 & 0.352 \\
\hline 1973 & 0.296 & 0.225 & 0.422 & 0.386 & 0.368 & 0.304 & 0.349 \\
\hline 1974 & 0.303 & 0.245 & 0.427 & 0.394 & 0.406 & 0.306 & 0.372 \\
\hline 1975 & 0.288 & 0.240 & 0.427 & 0.403 & 0.413 & 0.312 & 0.361 \\
\hline 1976 & 0.295 & 0.236 & 0.440 & 0.425 & 0.404 & 0.329 & 0.358 \\
\hline 1977 & 0.297 & 0.247 & 0.450 & 0.424 & 0.399 & 0.343 & 0.361 \\
\hline 1978 & 0.299 & 0.245 & 0.447 & 0.423 & 0.385 & 0.360 & 0.357 \\
\hline 1979 & 0.305 & 0.263 & 0.444 & 0.437 & 0.393 & 0.357 & 0.355 \\
\hline 1980 & 0.308 & 0.276 & 0.447 & 0.455 & 0.410 & 0.378 & 0.362 \\
\hline 1981 & 0.316 & 0.291 & 0.448 & 0.462 & 0.431 & 0.393 & 0.385 \\
\hline 1982 & 0.311 & 0.295 & 0.454 & 0.471 & 0.442 & 0.420 & 0.390 \\
\hline 1983 & 0.307 & 0.298 & 0.451 & 0.477 & 0.432 & 0.450 & 0.387 \\
\hline 1984 & 0.307 & 0.304 & 0.454 & 0.485 & 0.437 & 0.442 & 0.389 \\
\hline 1985 & 0.311 & 0.312 & 0.454 & 0.485 & 0.437 & 0.441 & 0.389 \\
\hline
\end{tabular}




$\begin{array}{lrlllllll}1960 & \text { NA } & 0.297 & \text { NA } & 0.331 & \text { NA } & \text { NA } & 0.344 & 0.275 \\ 1961 & \text { NA } & 0.285 & \text { NA } & 0.342 & \text { NA } & \text { NA } & 0.361 & 0.284 \\ 1962 & \text { NA } & 0.297 & 0.308 & 0.355 & 0.354 & \text { NA } & 0.372 & 0.292 \\ 1963 & \text { NA } & 0.290 & 0.323 & 0.355 & 0.361 & \text { NA } & 0.369 & 0.294 \\ 1964 & \text { NA } & 0.307 & 0.325 & 0.360 & 0.363 & \text { NA } & 0.379 & 0.300 \\ 1965 & \text { NA } & 0.316 & 0.355 & 0.368 & 0.390 & \text { NA } & 0.385 & 0.307 \\ 1966 & \text { NA } & 0.328 & 0.356 & 0.383 & 0.407 & \text { NA } & 0.393 & 0.324 \\ 1967 & \text { NA } & 0.346 & 0.365 & 0.405 & 0.428 & \text { NA } & 0.391 & 0.332 \\ 1968 & \text { NA } & 0.348 & 0.419 & 0.411 & 0.459 & \text { NA } & 0.389 & 0.338 \\ 1969 & \text { NA } & 0.338 & 0.427 & 0.433 & 0.469 & \text { NA } & 0.396 & 0.343 \\ 1970 & \text { NA } & 0.341 & 0.420 & 0.435 & 0.466 & 0.353 & 0.397 & 0.352 \\ 1971 & 0.464 & 0.357 & 0.433 & 0.466 & 0.494 & 0.363 & 0.405 & 0.357 \\ 1972 & 0.459 & 0.354 & 0.445 & 0.484 & 0.495 & 0.349 & 0.411 & 0.355 \\ 1973 & 0.468 & 0.360 & 0.459 & 0.496 & 0.477 & 0.345 & 0.419 & 0.364 \\ 1974 & 0.484 & 0.357 & 0.470 & 0.485 & 0.488 & 0.352 & 0.425 & 0.377 \\ 1975 & 0.461 & 0.378 & 0.492 & 0.496 & 0.505 & 0.346 & 0.429 & 0.404 \\ 1976 & 0.469 & 0.410 & 0.495 & 0.509 & 0.551 & 0.379 & 0.424 & 0.402 \\ 1977 & 0.476 & 0.403 & 0.505 & 0.510 & 0.580 & 0.364 & 0.437 & 0.416 \\ 1978 & 0.496 & 0.380 & 0.509 & 0.520 & 0.575 & 0.352 & 0.462 & 0.424 \\ 1979 & 0.508 & 0.360 & 0.514 & 0.519 & 0.564 & 0.359 & 0.458 & 0.431 \\ 1980 & 0.522 & 0.359 & 0.528 & 0.542 & 0.566 & 0.388 & 0.464 & 0.428 \\ 1981 & 0.521 & 0.376 & 0.535 & 0.528 & 0.583 & 0.396 & 0.478 & 0.436 \\ 1982 & 0.512 & 0.375 & 0.538 & 0.532 & 0.589 & 0.417 & 0.467 & 0.453 \\ 1983 & 0.536 & 0.375 & 0.553 & 0.531 & 0.599 & 0.439 & 0.463 & 0.447 \\ 1984 & 0.559 & 0.391 & 0.543 & 0.544 & 0.596 & 0.443 & 0.472 & 0.460 \\ 1985 & 0.570 & 0.405 & 0.544 & 0.561 & 0.594 & 0.445 & 0.477 & 0.465\end{array}$

Source: $O E C D$ National Income Accounts 
Table 5. Tests of Tax Rates as a Random Walk without Drift.

Dependent Varlable: Change in the Revenue to GDP ratio.

Country Independent Variable: Constant

\section{Sample:}

$1960 \cdot 1985$

$1960-1973$

\begin{tabular}{|c|c|c|c|}
\hline Austria & $\begin{array}{l}0.002 \\
(3.36)\end{array}$ & $\star$ & $\begin{array}{l}0.005 \\
(3.56)\end{array}$ \\
\hline Belgium & $\begin{array}{l}0.007 \\
(5.37)\end{array}$ & $\star$ & $\begin{array}{l}0.007 \\
(5.64)\end{array}$ \\
\hline Canada & $\begin{array}{l}0.005 \\
(2.96)\end{array}$ & $\star$ & $\begin{array}{l}0.007 \\
(3.60)\end{array}$ \\
\hline Denmark & $\begin{array}{l}0.009 \\
(2.57)\end{array}$ & $\star$ & NA \\
\hline Finland & $\begin{array}{l}0.004 \\
(1.61)\end{array}$ & & $\begin{array}{l}0.005 \\
(1.68)\end{array}$ \\
\hline France & $\begin{array}{l}0.005 \\
(3.78)\end{array}$ & $\star$ & $\begin{array}{l}0.003 \\
(1.59)\end{array}$ \\
\hline Germany & $\begin{array}{l}0.004 \\
(2.71)\end{array}$ & $\star$ & $\begin{array}{l}0.005 \\
(2.12)\end{array}$ \\
\hline Italy & $\begin{array}{l}0.006 \\
(2.82)\end{array}$ & $\star$ & $\begin{array}{l}0.001 \\
(0.65)\end{array}$ \\
\hline Ireland & $\begin{array}{l}0.006 \\
(2.06)\end{array}$ & $\star$ & NA \\
\hline Japan & $\begin{array}{l}0.005 \\
(3.38)\end{array}$ & $\star$ & NA \\
\hline Norway & $\begin{array}{l}0.009 \\
(4.38)\end{array}$ & * & $\begin{array}{l}0.012 \\
(5.15)\end{array}$ \\
\hline Netherlands. & $\begin{array}{l}0.006 \\
(3.29)\end{array}$ & $\star$ & $\begin{array}{l}0.013 \\
(2.78)\end{array}$ \\
\hline Swe den & $\begin{array}{l}0.007 \\
(2.56)\end{array}$ & * & $\begin{array}{l}0.011 \\
(2.43)\end{array}$ \\
\hline
\end{tabular}




$\begin{array}{lll}\text { United States } & 0.002 & 0.002 \\ & (1.29) & (1.10) \\ \text { United Kingdom } & 0.005 & 0.005 \\ & (1.89) & (1.28)\end{array}$

Note: t-statistics in parentheses.

NA: Not available for lack of data points.

* : Null hypothesis of zero drift refected at the 5 level.

**: For a few countries the sample does not go back to 1960 for lack of data.

Source: OECD National Income Accounts. 
Table 6. Test of the Theory of Optimal Selgnorage. 15 OECD countries. Dependent Variable: Inflation Rate.

Independent Varlables:

Country

Time Trend

Government Revenues

as a share of GDP

\begin{tabular}{|c|c|c|}
\hline Austria & $\begin{array}{l}0.001 \\
(0.37)\end{array}$ & $\begin{array}{r}-0.007 \\
(0.01)\end{array}$ \\
\hline Belgium & $\begin{array}{l}0.001 \\
(0.19)\end{array}$ & $\begin{array}{c}0.14 \\
(0.17)\end{array}$ \\
\hline Canada & $\begin{array}{l}0.00005 \\
(0.02)\end{array}$ & $\begin{array}{c}0.57 \\
(1.65)\end{array}$ \\
\hline Denmark & $\begin{array}{l}0.003 \\
(0.67)\end{array}$ & $\begin{array}{l}-0.58 \\
(0.96)\end{array}$ \\
\hline Finland & $\begin{array}{l}-0.001 \\
(0.48)\end{array}$ & $\begin{array}{c}0.88 \\
(2.00)\end{array}$ \\
\hline France & $\begin{array}{l}0.006 \\
(3.50)\end{array}$ & $\begin{array}{l}-0.64 \\
(1.79)\end{array}$ \\
\hline Germany & $\begin{array}{l}-0.001 \\
(1.00)\end{array}$ & $\begin{array}{c}0.47 \\
(1.64)\end{array}$ \\
\hline Ireland & $\begin{array}{r}0.007 \\
(1.30)\end{array}$ & $\begin{array}{l}-1.02 \\
(1.45)\end{array}$ \\
\hline Italy & $\begin{array}{c}0.01 \\
(4.66)\end{array}$ & $\begin{array}{l}.0 .74 \\
(2.16)\end{array}$ \\
\hline Japan & $\begin{array}{l}-0.003 \\
(0.35)\end{array}$ & $\begin{array}{c}0.17 \\
(0.13)\end{array}$ \\
\hline Norway & $\begin{array}{l}-0.002 \\
(0.62)\end{array}$ & $\begin{array}{c}0.50 \\
(1.65)\end{array}$ \\
\hline Netherlands & $\begin{array}{l}-0.01 \\
(3.43)\end{array}$ & $\begin{array}{c}1.25 \\
(2.76)\end{array}$ \\
\hline
\end{tabular}




$\begin{array}{lcc}\text { Sweden } & -0.002 & 0.40 \\ & (0.84) & (1.37) \\ \text { United Kingdom } & 0.0008 & 0.55 \\ & (0.25) & (0.92) \\ \text { United States } & -0.001 & 1.91 \\ & (0.84) & (2.68)\end{array}$

Source: IMF-IFS for inflation rates, OECD National Income Accounts for general government revenues.

t-statistics in parentheses. 
Table 7. Panel data regression of deficits with political variables.

Dependent Variable: DBY.

Variable

Equation

(1)

(2)

(3)

(4)

\begin{tabular}{|c|c|c|c|c|}
\hline DBYL & $\begin{array}{c}0.74 \\
(16.8)\end{array}$ & $\begin{array}{c}0.70 \\
(15.9)\end{array}$ & $\begin{array}{c}0.66 \\
(9.36)\end{array}$ & $\begin{array}{c}0.68 \\
(15.2)\end{array}$ \\
\hline DUB & $\begin{array}{c}0.21 \\
(2.72)\end{array}$ & $\begin{array}{c}0.16 \\
(2.05)\end{array}$ & $\begin{array}{c}0.15 \\
(1.93)\end{array}$ & $\begin{array}{c}0.10 \\
(1.32)\end{array}$ \\
\hline DRB & $\begin{array}{c}0.76 \\
(3.09)\end{array}$ & $\begin{array}{c}0.82 \\
(3.36)\end{array}$ & $\begin{array}{c}0.86 \\
(3.47)\end{array}$ & $\begin{array}{c}0.76 \\
(3.12)\end{array}$ \\
\hline DGR & $\begin{array}{l}-0.46 \\
(8.37)\end{array}$ & $\begin{array}{l}-0.45 \\
(8.18)\end{array}$ & $\begin{array}{l}-0.45 \\
(8.18)\end{array}$ & $\begin{array}{l}-0.44 \\
(8.04)\end{array}$ \\
\hline DUJAP & $\begin{array}{c}1.80 \\
(1.45)\end{array}$ & $\begin{array}{c}2.74 \\
(2.11)\end{array}$ & $\begin{array}{c}3.02 \\
(2.31)\end{array}$ & $\begin{array}{c}2.77 \\
(2.21)\end{array}$ \\
\hline POL & - & $\begin{array}{l}0.004 \\
(2.84)\end{array}$ & $\begin{array}{l}0.004 \\
(2.74)\end{array}$ & $\begin{array}{l}0.001 \\
(0.55)\end{array}$ \\
\hline POLD & - & - & - & $\begin{array}{l}0.005 \\
(2.11)\end{array}$ \\
\hline DBYLPOL & - & - & $\begin{array}{c}0.03 \\
(0.88)\end{array}$ & - \\
\hline 2 & 0.67 & 0.68 & 0.68 & 0.68 \\
\hline
\end{tabular}

Data Source: See Appendix.

t-statistics in parentheses. 
Table 8. France. Central Government Budget Deflclt as a share of GDP. $1950-1985$.

$\begin{array}{ll}1950 & -0.056 \\ 1951 & -0.040 \\ 1952 & -0.060 \\ 1953 & -0.054 \\ 1954 & -0.041 \\ 1955 & -0.038 \\ 1956 & -0.052 \\ 1957 & -0.049 \\ 19 & \ldots \\ 1958 & -0.028 \\ 1959 & -0.024 \\ 1960 & -0.014 \\ 1961 & -0.014 \\ 1962 & -0.017 \\ 1963 & -0.020 \\ 1964 & -0.004 \\ 1965 & 0.000 \\ 1966 & -0.004 \\ 1967 & -0.011 \\ 1968 & -0.015 \\ 1969 & -0.005 \\ 1970 & 0.005 \\ 1971 & -0.004 \\ 1972 & 0.007 \\ 1973 & 0.004 \\ 1974 & 0.005 \\ 1975 & -0.026 \\ 1976 & -0.010 \\ 1977 & -0.012 \\ 1978 & -0.014 \\ 1979 & -0.015 \\ 1980 & 0.000 \\ 1981 & -0.027 \\ 1982 & -0.031 \\ 1983 & -0.036 \\ 1984 & -0.030 \\ 1985 & -0.030 \\ 19\end{array}$

Source: IMF-IFS.

Note: De Gaulle came to power in July 1958 and the new constitution was promulgated in January 1959. 